\title{
Municipal Democracy and Risk of Municipal Democratization
}

\author{
Vladimir Konstantinovich Nikolaev ${ }^{1} \&$ Konstantin Alexeyevich Nikolaev ${ }^{2}$ \\ ${ }^{1}$ Far Eastern Federal University, city of Vladivostok, Russky Island, FEFU Campus, Russian Federation \\ ${ }^{2}$ Russian Presidential Academy of National, Economy and Public Administration, Moscow, Russian Federation \\ Correspondence: Vladimir Konstantinovich Nikolaev, Far Eastern Federal University, city of Vladivostok, \\ Russky Island, 690922, Ajax Bay, 10, FEFU Campus, Russian Federation. E-mail: nikolaev.vk@dvfu.ru
}

Received: March 23, 2015 Accepted: May 12, 2015 Online Published: July 30, 2015

doi:10.5539/ass.v11n19p281 URL: http://dx.doi.org/10.5539/ass.v11n19p281

\begin{abstract}
Research of empiric experience of civic participation in the local self-governance in contemporary Russia shows an incomplete picture of scholarship on the issues of municipal democracy along with the conditions of its development and the possible risks imposed by such a development. A performed analysis allows formulating definitions of some of the key terms of civic participation in the local self-governance. Municipal democracy here is defined as a political regime in which a municipal public authority is carried out through the direct rule of people by means of election of members of the local parliaments with assistance of the executive bodies and with an active popular participation in the exercise of the local self-governance with an ultimate goal of sustaining life of a local community. In turn, a municipal political regime is introduced as a unity of formalized written and unwritten rules and procedures of formation of local self-government bodies, of their interactions related to the decision-making and the management of the municipal resources and their relations with the state governing structures, civil society institutions, federal, regional and local elites, and citizens. The term 'risk of municipal democratization' is introduced to reflect a situation in the local political system, where there exists a probable danger that if one of the different alternative options of exercise of local self-governance in the local municipality is selected, a choice of it can lead to a failure of attainment of specified goals, or to a non-resolution or a poor resolution of issues of local significance. Besides, the work also identifies the key points of risk management in the sphere of municipal democracy.
\end{abstract}

Keywords: local self-government, municipal democracy, municipal political regime, risk, risk of municipal democratization, municipal democratization risks management

\section{Introduction}

In the literature on the local self-government theory, one of the main principles of the local self-government is considered to be a principle of local or municipal democracy (Explanatory note 1), which implies a combination of representational democracy and direct expression of the citizens' will, thus emphasizing a political theory understanding of this term. The preamble of the European Charter of Local Self-Government emphasizes that the citizens' right to participate in the conduct of public affairs as a democratic principle and expresses a conviction that this right can be exercised most directly on the local level (European Charter of Local Self-Government, 1985). In turn, the European Urban Charter consolidated the provision that the basis of urban development must be direct citizen participation, within a local authority which itself enjoys as much autonomy and fiscal independence as possible (European Urban Charter, 1992, S.3.3.). Nikolai Bondar writes about a relatively new phenomenon of democratic reality, namely institutions of municipal (local) democracy, which "represent an integral component of sovereign Russian state identity". He emphasizes that "municipal democracy in its present-day understanding is an international law acknowledged universal legal institution of democratic organization of today's civil society and a state, governed by the rule of law" (Bondar, 2008, p. 5). Isa Tochiev in his doctoral dissertation summary writes about the importance of development of the democratic component of municipal government, primarily, in the field of exercising the citizens' right for self-government in the context of political system's modernization and democratization processes, which among other things would include management operations (Tochiev, 2013, p. 16).

As can be seen from above, an encouragement of expansion of population's participation in the local self-government becomes a contemporary trend in the development of municipal communities. 
At the same time some scholars note that municipal democracy also carries out a certain contradictions. Nikolai Bondar, for instance, writes about possible contradictions of the modern democracy associating them with the following factors. First, inconsistency of private and public, federal and regional, national and municipal interests. Second, opposition of the role functions and interests of actors of democratic processes. Third, 'ripening' of the social conflicts and their transformation into legal, political, authoritative and economic spheres at a certain level of democratic transitioning (Bondar, 2008, p. 13). Leonid Tapman argues that one of the elements of a democratic process, related to the evaluation and selection of alternatives as well as a practical implementation of the decisions made at the condition of incomplete predictability of the future outcomes, comes to exist as a political risk (Tapman, 2002, p. 57).

Hence, it is fully justified to interconnect an analysis of municipal democratization processes with consideration and where possible with the management of risks inflicted by these processes. However, there is an obvious insufficiency of scholarship on the issues of municipal democracy and the risks of a process of municipal democratization. This article attempts to answer the following questions: What is the essence of such phenomenon as municipal democracy? What is the risk of municipal democratization? What is the risk field in the sphere of municipal democracy? What are the possible approaches towards the management of the risks of municipal democratization?

\section{Methods}

To answer the questions addressed in this paper the authors have conducted a comparative analysis of approaches used to define 'democracy' and 'risk' as umbrella terms for such terms as 'municipal democracy' and 'risk of municipal democratization' along with the term 'political risk', one of varieties of which is associated with a risk of expansion of municipal democracy.

Analysis of the term 'democracy' on the one hand shows that it is "an equal access of citizens to the exercise of power" (Kara-Murza, 2008, pp. 64-65) that it is "a rule of people, or participation of people in the conduct of public affairs..." (Vodolazov, 2008, p. 71). Andrew Heywood, quoting the words of Abraham Lincoln's Gettysburg address speech of 1864 about democracy being a "government of the people, by the people, for people", suggests perceiving democracy as a link between the government and the people. Moreover, this link can exist in different forms: as a rule by the people, as a rule of those who represent people, and as a rule in the public interest (Heywood, 2005, p. 84). In the dictionary of political terms Heywood defines democracy as a rule of people that implies "both popular participation and government in the public interest" (Heywood, 2005, p. 512). Philippe Schmitter comparing corporatism and democracy outlines the following features of democracy among nations: regularly held elections, conducted on a competitive basis with uncertain outcomes; accountability of authorities for their actions and implementation of policies that would match the demands of the people (Scmitter, 1997). On the other hand, the term 'democracy' has always had different interpretations from both historical and philosophical perspectives (Kara-Murza, 2008, p. 63), and so it does today becoming a 'hurray! word', which complicates the use of this term as "a meaningful political concept" (Heywood, 2005, p. 104). Besides, Heywood ironically observes that “...we are all now democrats. Liberals, conservatives, socialists, communists, anarchists and even fascists are eager to proclaim the virtues of democracy and to demonstrate their own democratic credentials." (Heywood, 2005, p. 82)

Analysis of the term 'risk' also gives an evidence of the differences of its interpretations. Frank Knight, addressing uncertainly and risk in economics, describes risk as an objective, cognizable, measurable phenomenon, which constitutes a potential danger or an already inflicted damage (Knight, 2003). Scholars suggest understanding risk as any event or action that can produce a negative effect on the attainment of certain goals (Barton et al., 2003, p. 15), or as probable diversion from the expected outcome (Elliott, 2007, p. 3). At the same time there is an opinion, which implies that risk is a "situation, related to the presence of choice among suggested alternatives in the way of evaluation of a possible occurrence of a risky event, which can lead to both positive and negative outcomes." (Yegorova, 2002, p. 9)

When it comes to the term 'political risk', it most often is associated with the dangers imposed on businesses by the political system of states (Zonis \& Wilkin, 2004). Having analyzed a number of definitions of the term 'political risk' in the context of business development Anatoly Algin offers his definition of this term: "Political risk is a probability of occurrence of political factors in the country (or the region), which can produce both positive and negative effects on the managerial, economic and other types of activities." (Algin, 2006, p. 347) At the same time there also exists an opinion, which in the analysis of the term 'political risk' diverts attention away from the economic characteristics. In such a manner, for instance, Gorshkova suggests understanding political risk as a "probability of adverse consequences of political decisions made in conditions of uncertainty, deficit of 
resources (i.e. time, information, etc.), which results in a damage for participants of political actions and in a probability of undesirable events." (Gorshkova, 2001, p. 140)

\section{Results}

A performed analysis of approaches towards understanding of the term 'democracy' (Nikolayev \& Nikolayev, 2010 , p. I) allows coming to the following conclusions. First, democracy could be understood as such a political regime, or such an organization of a political system where political power is exercised by means of direct rule of people or also by means of rule of their representatives, elected by population or by its fraction in the interests of the voters. Second, democracy is often perceived as a certain value, characterized by a number of features, which are formulated based on the analysis of experience of organization of state and political life of countries, which are considered to have a developed democracy. Gregory Rzheshevsky, for instance, points out to the fact that the term 'democracy' in reality is understood not as a rule of people, but rather as a combination of properties of socio-political structures and systems of management, which have formed in the most successful countries (Rzheshevsky, 2008, p. 91) Third, certain difficulties exist in the formulation of the term 'democracy' due to the presence of different models of democracy. More specifically one could identify classical democracy as a way of exercise of people's self-governance, protective democracy as a way to guarantee a maximum of individualistic freedom of choice of pursuit of happiness, developmental democracy as embodiment of a wide political participation, people's democracy as a way of implementation of economic emancipation, liberal democracy as an indirect representative form of democracy based on regularly held elections (Heywood, 2005, pp. 104-105). Fourth, often the term 'democracy' people prefer to associate with a certain set of procedures of formation of the institutions of power and decision-making. In this vein Joseph Schumpeter characterizes philosophy of democracy both in the framework of classical theory and in the framework of competitive leadership theory, as he prefers to speak about democratic method as a combination of institutional means and arrangements (Schumpeter, 1995). Schmitter in his turn puts an emphasis on the fact that contemporary democracy is a combination of diverse institutions of representation and of centers of authoritative decision-making, which besides voting also covers selection of candidates, protest rallies, membership in associations, petitioning of the government, and many more (Schmitter, 1996). Fifth, a general acceptance of a value of democratic principles for a present-day society does not impede discussions on the ways and mechanisms of practical implementations of these principles. Consequently, there emerge varied theoretical constructs, which identify potential opportunities and limitations of concrete regimes of government, among them being such concepts as 'pluralist democracy', 'consociational democracy', 'elitism', 'competitive leadership', 'corporatism', 'neo-corporatism', etc.

Analyzing different approaches towards definition of the term 'risk', it is reasonable to proceed from the following. First, to understand risk it is important to answer the following question: what is the circumstance of the risk emergence? Most frequently circumstance in this case is understood as a phenomenon that either accompanies another phenomenon or is related to it, or as a condition that defines the status or existence of somebody or something, or as a certain setting. At the same time risk depends on such circumstances as the procedures of goal-setting, as availability or lack of information, as a choice of an alternative and a danger associated with it, or as a probability of materialization of an opportunity. In this regard it seems justifiable to use the word 'situation' (from French 'situation') for definition of the term 'risk', which is understood as a condition or as a combination of circumstances. Second, risk should be referred not to the present, but to the future, which exists as a potential possibility in the present. It is not accidental that Ulrich Beck points out to the fact that debate about the risk is the debate about something that does not exist, but what could possibly turn into reality in case if an opposite direction of action is taken in the present (Beck, 2001, p. 176). Third, it is hardly justifiable to relate risk to the positive consequences, as it is sometimes done. It is for a reason that Frank Knight relates risk specifically to the danger of something. Beck assumes that a firmly established definition of risk supposes to teach society to fear and thus to become more active and to politicize (Beck, 2001, p. 176). Based on these assumptions, risk can be defined as a term, which reflects a situation, which is characterized by a danger when in the presence of diverse alternative options choosing one of them may result in a failure of goal attainment. In such case, political risk, as a term, reflects a political situation characterized by a danger when, in the presence of diverse alternative options of political decisions, choosing one of them may result in a failure to succeed, in a damage for participants of political actions or in a damage for attainment of their goals (Nikolayev \& Nikolayev, 2010, pp. $123 \&$ II). 


\section{Discussion}

\subsection{Municipal Democracy: Values Characteristics and Definition}

Based on the conducted analysis of the term 'democracy', on the understanding of the local self-governance as a specific form of rule by people in the framework of a limited territorial (local) system, and also considering the general principles of democracy proposed by the Bureau of International Information Programs of the US Department of State (Principles of Democracy, 2004), the following value characteristics of the municipal democracy could be identified:

1) Municipal democracy is such a form of organization of local self-governance where:

a) Population of the municipal entity, having the right to vote in accordance with the law, participates in the resolution of the issues of local significance independently and under its own responsibility either directly or through elected bodies and officials of the local self-government;

b) Municipal entity's population has real opportunities (either directly or through their representatives) to adopt municipal regulatory acts and to change local self-government's officials performing executive and administrative functions while not elected by the population directly;

c) Expression of will of the population's majority is provided for; the rights of population's minority and personal rights are observed; the conflicts are managed and, when arising, used for the purpose of development of the democratic process and for the purpose of social and economic development of the municipal entity (Explanatory note 2);

d) Local authority is decentralized and a part of its powers is delegated to the level of territorial public self-government (Explanatory note 3) and other forms of population's self-organization taking over the initiative on participation in the resolution of the local issues;

e) Comprehensive opportunity is granted to express the unique features of political, social and cultural life of the municipal community within the scope of the existing legislation.

2) Municipal democracy is a combination of principles and practical measures that aim to protect:

a) Constitutional rights and liberties of a person and a citizen on the territory of a municipal entity in the scope of competency of a local self-government;

b) Municipal rights and liberties as an assurance of comprehensive opportunities of civic participation in the exercise of local self-governance, as the municipal authority's obligation to resolve issues of local significance and to provide for everyone's equal access to municipal services of high-quality.

3) Municipal democracy presupposes a presence of municipal public politics as an indication of competition between diverse interest groups and public associations, including political parties, specific persons known to the population of the municipal entity, for acknowledgment and public votes along with a provision of periodically held free municipal elections and local referenda.

4) Municipal democracy presupposes:

a) That residents, local self-government bodies and officials along with the municipal employees strictly observe laws and municipal regulatory acts;

b) Local community's members taking over obligations of feasible participation in municipal activity in all of its diversity;

c) Providing for implementation of such principles as tolerance, close cooperation and attainment of compromise in interpersonal communication and interaction of local self-government officials and municipal employees with the civil society institutions, acting in the municipal entity, and with the community residents.

5) Municipal democracy provides protection of the municipal entity's population from abuse of power on the part of officials of local self-government bodies and municipal employees.

When it comes to the definition of the term 'municipal democracy', it appears important not to limit its scope only to its political theory aspect in a form of a population's participation in the elections of bodies of the local authority. In mid-'90s, Igor Pantin in the discussion about the values of democracy highlighted an important lesson from the world history, saying that "the fight for democracy only, the fight for pure democracy being isolated from social problems and the strategy of economic renewal results in the victory of the narrower interests over the wider ones." (Pantin, 1996, p. 6) And today, the local level experiences give enough evidence to suggest that when municipal democracy is only limited to the issues of procedure of formation of the local 
self-government bodies and does not create real conditions for socio-economic development of a municipal entity, the essence of the local self-government becomes undermined. When population and local authorities turn out to be separated or even set against each other, narrow group or clan interests win over the wide social interest of the territory's development. Municipal democracy here is defined as a political regime in which a municipal public authority is carried out through the direct rule of people by means of election of members of the local parliaments with assistance of the executive bodies and with an active popular participation in the exercise of the local self-governance with an ultimate goal of sustaining life of a local community.

\subsection{About the Rationale behind the Use of the Term "Municipal Political Regime"}

The term 'municipal political regime' becomes a core term in the practical analysis of such matters as municipal politics, implementation mechanism of municipal public authority and civic participation in the local self-government, although this term is uncommon in specialized literature on municipal law and local self-governance theory. Currently there exists a common understanding that this term is intended to describe the mechanisms of exercising of power of the state, although there is no consensus yet on this term's definition, which would allow formalizing its essence. Researchers have identified two main approaches in the analysis of political regime issues: a legal and a sociological one. The first approach analyzes legally established and often constitutionally codified formal institutions, norms and rules of exercising of power. The second, sociological approach, analyzes primarily those mechanisms that help exercise the real political authority along with the link existing between the state and the society (Yeliseyev, 2006. p. 39) The second approach also offers an opportunity to discuss issues of a political regime within the field of political regional studies considering the regional level of public authority, which would demand such a definition of the term 'political regime' that would allow to apply it to the exercise of public authority on a concrete territory within a framework of a federal state. Consequently here political regime is understood as a "combination of political actors, having certain resources and implementing varied strategies, and of institutions (i.e. norms, rules of the game)" (Kuzmin et al., 2002 , p. 143); or as an "interrelated combination of political actors existing on a certain territory (with their methods of exercising of power, resources, goals and strategies) and institutions (understood both as organizations and as norms, rules of the game)." (Turovsky, 2009, p. 78) Besides, during analysis of the problems of different political regimes a special attention is attributed to the consideration of such indicators as the procedures and the ways of formation of institutions of power, the styles of political decision-making, and the relations of authorities and citizens, etc.

At the same time, indicators listed above can also be used to analyze municipal political life. For on the one hand different electoral systems could be utilized during municipal elections held with the purpose to form local bodies of authority, among others including the party lists. On the other hand decision-making by the bodies and the officers of the local self-government is often lobbied by diverse political actors, such as local branches of political parties, representatives of business, public interest group, etc. Generally speaking, on the territories of larger cities and municipal districts political processes take impassioned forms, methods and directions of political activity of diverse actors. In addition, these processes can be regulated with formal legal institutions, with diverse informal, written and unwritten rules and norms, and frequently they can be not regulated at all elapsing spontaneously and unpredictably (Usmanova, 2013).

Thus, the term 'municipal political regime' can become a new important construct that would encourage analysis of both comprehensive mechanisms of municipal democracy and the democratic processes of formation and exercise of the state authority. Schmitter, for instance, offering to consider democracy as a combination of 'private regimes' institutionalized around specific fractions of a society, pointed to the fact that in the framework of such 'private regimes' parties, associations, movements and territories, competing and cooperating with each other, fight for the public offices and for the influence on the national politics (Schmitter, 1996). When it comes to the definition of the term 'municipal political regime', the following interpretation could be attributed to it: municipal political regime is unity of formalized written and unwritten rules and procedures of formation of local self-government bodies, of their interactions related to the decision-making and the management of the municipal resources and their relations with the state governing structures, civil society institutions, federal, regional and local elites, and citizens. An analysis of a municipal political regime in the framework of a concrete municipal community should allow uncover real-life often hidden processes of authoritative and managerial actions of local authorities along with alignment of authoritative and political forces in the decision-making, which affect the interests of a municipal community, and together with that should characterize individuals and their alliances, who have the real right to make such decisions. 


\subsection{About the Issue of Municipal Risk of Democratization and the Risk Field in the Sphere of Municipal Democracy}

Supposing that one of the types of political risk would be the risk related to the expansion of municipal democracy and to the expansion of civic participation in the local self-governance, and also in order to conduct a more comprehensive analysis of democratization of municipal life, this paper's authors suggest introducing the term of 'risk of municipal democratization'. This term is intended to reflect a situation in the local political system, where there exists a probable danger that if one of the different alternative options of exercise of local self-governance in the local municipality is selected, a choice of it can lead to a failure of attainment of specified goals, or to a non-resolution or a poor resolution of issues of local significance (Nikolayev and Nikolayev, 2010, pp. 124 \& II). A special feature and advantage of such a definition of risk of municipal democratization on the one hand may be its ability to reflect the specificity of the concrete municipal community given its territorial limits, and on the other hand to evaluate the situation in the region and the nation as a whole. Besides, risk of municipal democratization, becoming an integral and essential part of municipal affairs, is directly connected to the municipal political process and municipal management, to the expression of proactive attitude of actors of the municipal political processes towards the political reality of the specific municipal entity, presupposing an obligation to manage this kind of municipal risk.

As the experience of exercise of local self-governance demonstrates, an effective facilitation of civic participation in the local self-governance depends on numerous factors, which may create a risk field in the sphere of municipal democracy. We suggest to understand a risk field in the sphere of municipal democracy as the local political space where under the influence of social relationships related to the exercise of the local self-governance, there form the factors that encourage occurrence of the risk situations. During analysis of factors that encourage occurrence of the risk situations scholars commonly divide them into the two main groups: objective and subjective ones. In our case, objective factors are the factors, which are accepted as given by the local political actors and which they may influence only to a certain extent. In their turn, subjective factors are the factors generated by the local political actors independently due to their decisions and actions.

The following is suggested as objective factors that encourage occurrence of the risk situations in the sphere of municipal democracy: a) state policy in the sphere of local self-governance, which embodies predominantly in the federal and regional laws that regulate an exercise of the local self-governance and a civic participation in it; b) initial state of socio-economic, cultural and political development of the municipal entity; c) population of a specific municipal entity with its cultural, civic and political characteristics and a particular degree of preparedness for civic participation in local self-governance; d) degree of matching of the local self-government body system to the structural connections of these bodies in a concrete municipal entity; degree of matching of the procedure of their formation to the political, managerial, social, economic, spiritual capacities of the municipal community; e) presence of diverse institutions of civil society and conditions for competition between local political actors and municipal democracy actors on the territory of the municipal entity. The following is suggested as subjective factors that encourage occurrence of the risk situations in the sphere of municipal democracy: a) exercise of policy-making by the members of municipal parliament, which can be ineffective and inadequate to the real life situation in the sphere of municipal democracy on the territory of a municipal entity, imposing restrains and limitations to the civic participation in the local self-governance; b) executive and administrative activity of municipal entity's employees, which may contravene the requirements of municipal democracy's implementation and ignore the results of civic participation in local self-governance; c) activity of the party structures and the organizations created by them along with activity of the civil society institutions, if it would contravene the requirements of municipal democracy's implementation and would not meet the municipal interests and the interests of the municipal entity's community, could present a real danger of destabilization of political, social and economic situation in the municipal entity (Nikolayev \& Nikolayev, 2010, pp. 124-125 \& II).

In general, a specific list and analysis of objective and subjective factors that encourage creation of risk situations in the field of municipal democracy can be reasonably attributed not only to each type of municipal entities, but also to each municipal entity. This is due to the fact that implementation of the local self-governance, emergence of a municipal political regime and democratization processes in real life would essentially be unique for each type of municipal entities and for each municipal entity individually.

\subsection{On the Issue of Management of Risks of Municipal Democratization}

As was mentioned above, acknowledgment of advisability of the use of the term 'risk of municipal democratization' is important because specific risks may and should be managed to the benefit of development 
of a certain territory or municipal community. The necessity of such management is based, at least, on the following considerations. First, market relationships that inevitably penetrate all aspects of the municipal community's life along with scientific and technological progress and global cultural processes change objective and cultural environment demanding that people pursue their own independent activities, demonstrate creativity, use lateral thinking in their decision-making and in their actions. Involvement of larger number of people who possess these personal characteristics into the processes of municipal politics and decision-making on the matters that affect interests of a municipal community can lead to the situation, when reaching a consensus on the matter of choice of alternatives of a certain decision to be made would be simply impossible. Second, socio-economic development of the municipal entity requires coordinated actions of local self-government bodies and officials with various economic entities, civic institutions, regional and federal authorities and administrations that often have varied or even opposing interests, which may not coincide with the real-world interests of the municipal community. Since the participants of this process can have unequal influence opportunities on the decision-making on the issues of socio-economic development of the municipal entity, it becomes possible to promote narrow, group or clan interests under the cover of democratic procedures. Third, it becomes possible to pursue the interests of the minority under a condition of varied degree of activeness of different institutions of civil society and of social groups in the processes of the municipal politics especially in the municipal elections, which can lead to the disruption of the socio-political life on the territory of the municipal entity.

A performed analysis of the most frequently used definitions of the term 'risk management' with consideration of terminology applied in this case allows suggesting the following interpretation of the term under consideration. Risks management of the municipal democratization is the system of methods and techniques-based ability to: a) elicit and evaluate a risk situation in the municipal political system; b) prevent an abuse of the democratic procedures, which can be at odds with the interests of the municipal community and socio-economic development of the municipal entity. Based on the commonly acknowledged understanding of the management process, the risks management of municipal democratization in general can consist of the following stages. The first stage is the planning of the process of municipal democratization risks management. Here it is reasonable to address the issue of entitlement of specific individuals and agencies with the authority on the management of specific risks such as drafting of the model plan templates, process of risks management timing, selection of the specific techniques of risk evaluation, identification of the risks threshold level based on the formulated criteria, etc. The second stage is identification and evaluation of the municipal democratization risks factors. This stage is supposed to address the issues of collection and processing of the information, which relates to the risks in the sphere of municipal democracy, to the ranging of risks, to identification of the conditions where they can emerge, to the qualitative and quantitative analysis of the risks. It is important that the qualitative analysis can reveal the sources and the reasons of the risks, it can forecast the consequences of the risk-containing situations and single out measures that would address the risks. The quantitative analysis should evaluate the identified risks. The third stage is the planning of response to the risks in accordance with the specified parameters, which in other words would be a development of a series of measures aimed to protect the development of municipal democracy from the undesired risks exposure. At this stage different measures of risk protection are taken into consideration together with evaluation of efficacy of different response options, which include risk reduction, risk-taking and risk transfer to the third parties. The fourth stage is monitoring and control of municipal democratization's development results on the territory of the municipal entity. This stage implies arriving at conclusions that would contain information on the exposure of the identified risks, which would define permissible and impermissible deviations from initially formulated parameters for each risk, and which would evaluate efficacy of selected measures of risk response. This stage may include the correction of the decisions taken earlier, and as a result may feature revision of a plan on risks response in the sphere of municipal democracy.

\section{Conclusion}

It appears that issues considered in this article can encourage analysis of processes of democratization on the territory of concrete municipal entities, and as a result can elicit a degree of real participation of citizens in the exercise of the local self-governance and can identify reasons that can impede such a participation, along with the development of measures that eliminate these reasons.

However, at the same time the framework of this article would not allow a seemingly interesting attempt to identify a place and role of municipal democracy among such contemporary constructs as 'pluralist democracy', 'consociational democracy', 'competitive leadership', 'neo-corporatism', etc.

A serious research work is needed to help merge theoretical constructs related to the formulation of a) definitions of such terms as 'municipal democracy' and 'municipal political regime', b) value characteristics of municipal 
democracy with comprehensive procedures of exercise of municipal politics on a concrete territory. It appears promising and interesting to analyze the municipal political regime and the risk field in the sphere of municipal democracy on the territory of concrete communities, municipal districts and to evaluate what sort of influence it produces on the democratic processes in both the regions and the nation.

Scholarship of issues of management of municipal risks, both in the sphere of municipal democracy and in diverse fields of municipal affairs related to the complex socio-economic development of municipal entity remains to be an important problem. Unfortunately, no real management system of such risks has been created to date in the majority of municipal entities of Russia. Only several attempts have been made to develop specific techniques, which could be offered as recommendations for interested municipal agencies (Suchkov, 2010). To address the challenges of the management of risks of municipal democracy scholars would need to identify the areas of focus along with parameters and indicators, which could be used for analysis of the existing condition and the future development of the municipal democracy together with the civic participation in the local self-government.

\section{References}

Algin, A. P. (2006). Public Management in Conditions of Risk and Emergencies. Public Policy and Management. Textbook (2nd parts, Part I). In L. V. Smorgunov (Ed.), Concepts and Problems of Public Policy and Management (pp. 346-372). Moscow: Rossiyskaya Politicheskaya Entsiklopediya (Russian Political Encyclopedia).

Barton, T. L., Shenkir, W. G., \& Walker, P. L. (2003). Complex approach to risk management: Is it worth dealing with risk management (p. 208). Russian Edition. Moscow. Williams Publishing House.

Beck, U. (2001). What is Globalization? (p. 304) Translation from German by A. Gregoryev and V. Sidelnik. Editing and concluding remarks by A. Philippov. Moscow. Progress-Traditsiya Publishing.

Bondar, N. S. (2008). Local Self-Government and Constitutional Justice: Constitutionalization of Municipal Democracy in Russia (p. 278). Norma Publishing House.

Elliott, M. W. (2007). Risk financing (p. 136). Russian edition. Translated by I. B. Kotlobovsky. Moscow. INFRA-M Publishing House.

European Charter of Local Self-Government. (1985). Retrieved January 13, 2015, from http://base.garant.ru

European Urban Charter. (1992). Retrieved January 9, 2015, from http://uristinfo.net

Gorshkova, A. A. (2001). Political Risk and Methods of Its Optimization (p. 140). Important Problems of Political Studies: Collection of Papers by Students and Graduate Students of People's Friendship University of Russia. Editor-in-chief: doctor of philosophical sciences, professor V. D. Zotov. Moscow: MAKS Press.

Heywood, A. (2005). Politics (p. 544). Russian Edition translation by G. G. Vodolazova, V. U. Belsky. Moscow. UNITY-DANA.

Kara-Murza, A. A. (2005). Proceedings of the "Democracy: Universal values and diversity of historical experiences" Round Table Discussion (Vol. 5, pp. 63-65). Polis Publishing House.

Knight, F. H. (2003). Risk, Uncertainty and Profit (p. 360). Russian edition. Moscow.

Kuzmin, A. S., Melvin, N., \& Nechaev, V. D. (2002). Regional Political Regimes in Post-Soviet Russia: The Typologization Experience, Polis, 3, 142-155.

Nikolayev, V. K., \& Nikolayev, K. A. (2010). On the Issue of Municipal Democracy (p. 104). Edited by S.Y. Naumov. Saratov: Povolzhskaya Akademiya Gosuderstvennoy Sluzhby imeni P. A. Stolypina (P. A. Stolypin Povolzhye State Service Academy).

Nikolayev, V. K., \& Nikolayev, K. A. (2010). On the Issue of Risk of Democratization on the Municipal Level (Vol. 5, pp. 112-129). Contemporary Issues of Political Science. Saratov: Povolzhskaya Akademiya Gosuderstvennoy Sluzhby imeni P. A. Stolypina (P. A. Stolypin Povolzhye State Service Academy).

Pantin, I. K. (1996). Proceedings of the Round Table Discussion: Philosophy and Politics. Questions of Philosophy Journal, 1, 5-7.

Principles of Democracy. (2004). Retrieved August 10, 2010, from http://www.infousa.ru/government/principles _files/what.htm

Rzheshevsky, G. A. (2008). Democracy: Myth, Reality or a Brand Well-Promoted? (Vol. 5, pp. 90-98). Polis Publishing House. 
Schmitter, P. (1996). Some Propositions about Civil Society and Consolidation of Democracy (Vol. 5, pp. 16-27). Polis Publishing House. Retrieved February 9, 2015, from http://society.polbu.ru/political_science/ch 34_all.html

Schmitter, P. (1997). Neo-corporatism (Vol. 2, pp. 14-22). Polis Publishing House. Retrieved February 9, 2015, from http://society.polbu.ru/political_science/ch34_all.html

Schumpeter, J. (1995). Capitalism, Socialism and Democracy. Moscow. Retrieved from http://www.gumer.info/ bibliotek_Buks/Polit/Schum/index.php

Suchkov, D. I. (n. d.). Risk Management of Municipal Entities. Bulletin of Irkutsk State Economic Academy (Vol. 4). Retrieved February 13, 2015, from http://cyberleninka.ru/article/n/upravlenie-riskami-munitsipalnyh -obrazovaniy\#ixzz2iu2Y4maU

Tapman, L. N. (2002). Risks in the Economy (p. 380). College Textbook. Edited by professor V. A. Shvandar. Moscow. UNITY-DANA Publishing House. Retrieved February 13, 2015, from http://institutiones.com/ general/1225-riski-v-ekonomike.html

Tochiev, I. B. (2013). Democratization of the Municipal Management System in the Context of the Russian Society's Political Modernization. Summary of Doctoral Dissertation for Competition of the Degree of Candidate of Sociological Studies (22.00.08 "Management Sociology"). Rostov-on-Don.

Turovsky, R. F. (2009). Regional Political Regimes in Russia: On Analysis Methodology (No. 2, pp. 77-95). Polis.

Usmanova, R. M. (2013). Political Relationships in the Local Self-Government System: Concept and Participants. Historical, Philosophic, Political and Legal Sciences, Cultural Studies and Art History. Issues of Theory and Practice, 1(27), 193-197. Retrieved February 14, 2015, from http://www.gramota.net/ materials/3/2013/1-2/44.html

Vodolazov, G. G. (2005). Proceedings of the "Democracy: Universal values and diversity of historical experiences" Round Table Discussion (Vol. 5, p. 71). Polis Publishing House.

Yegorova, E. (2002). Once again about the essence of risk and the system approach... Risk management, 9-12.

Yeliseyev, S. M. (2006). Political Regimes: Public Policy and Management. Public Policy and Management. Textbook (2nd parts, Part I). In L. V. Smorgunov (Ed.), Concepts and Problems of Public Policy and Management (pp. 39-51). Moscow: Rossiyskaya Politicheskaya Entsiklopediya (Russian Political Encyclopedia).

Zonis, M., \& Wilkin, S. (2004). Driving defensively through a minefield of political risk (pp. 199-204). In James Picford. Mastering Risk (Russian edition translation by O. N. Matveyeva). Moscow. Vershina Publishing House.

\section{Notes}

Note 1. In the Russian legislation and the literature on the local self-governance the terms 'local' and 'municipal' along with the terms and expressions based on them are considered to be synonymous when it comes to the consideration of issues of exercise of the local self-governance by the population.

Note 2. The term 'municipal entity' in the Russian legislation and the literature on the local self-governance implies a limited populated territory, where the municipal community exercises a local self-governance.

Note 3. Territorial public self-government in the Russian legislation and the literature on the local self-governance implies a self-organization of the local population on the territorial principle with the purpose of implementation of its own initiatives on resolution of issues of local significance. By its meaning this term is close to such terms as 'neighborhood' and 'community'.

\section{Copyrights}

Copyright for this article is retained by the author(s), with first publication rights granted to the journal.

This is an open-access article distributed under the terms and conditions of the Creative Commons Attribution license (http://creativecommons.org/licenses/by/3.0/). 